\title{
COVID-19: The Patients' Perceived Impact on Dental Care
}

\author{
Alessandra Amato ${ }^{1}$ Alfredo landolo ${ }^{1}$ Giuseppe Scelza ${ }^{1}$ Francesca Spirito ${ }^{1}$ Stefano Martina ${ }^{1}$ \\ ${ }^{1}$ Department of Medicine, Surgery and Dentistry, Scuola Medica \\ Salernitana University of Salerno, Baronissi, Italy \\ Eur J Dent 2022;16:333-338. \\ Address for correspondence Stefano Martina, DDS, PhD, Department \\ of Medicine, Surgery and Dentistry, Scuola Medica Salernitana \\ University of Salerno, Via Allende, 84081 Baronissi, Italy \\ (e-mail: smartina@unisa.it).
}

\begin{abstract}
Keywords

- aesthetics

- COVID-19

- dental practice

- diet

- survey

Objectives The present study aims to investigate the effect of the COVID-19 pandemic on people's mental and physical balance, oral hygiene habits, type of diet, perceived safety of returning to the dentist, and aesthetics with the use of masks. Materials and Methods An online questionnaire was submitted to the Italian population between December 2020 and January 2021. It was sent via online platforms and included 21 questions.

Statistical Analysis Differences in rates were calculated by using the Chi-square test. The level of significance was set at $p<0.05$.

Results A total of 1,008 individuals completed the questionnaire. About $72 \%$ of participants were not concerned about returning to the dentist. Approximately $45 \%$ of the individuals intensified their oral hygiene and preventive rules. About $38 \%$ of participants increased their carbohydrate intake, while 28\% increased their fat consumption. Furthermore, $75 \%$ of the participants felt that the mask did not diminish the beauty of their smile.

Conclusions Most participants felt comfortable returning to the dentist but only for more urgent treatment. However, most people reported that they had not stepped up their home oral hygiene measures. The biggest changes in the population's eating habits involved increased carbohydrate and fat consumption. Finally, most participants responded that mask use did not compromise their aesthetics.
\end{abstract}

\section{Introduction}

In December 2019, a new viral infection broke out in Wuhan, a city in central China. ${ }^{1}$ In January 2020 , the etiologic agent was identified and named Severe Acute Respiratory Syndrome Corona Virus 2 (SARS-CoV-2). ${ }^{2}$ The World Health Organization (WHO) recognizes the disease as COVID-19, an acronym derived from the combination of the terms " $\mathrm{Co}$ rona Vi-rus D-isease" and the year of identification 2019. ${ }^{3}$ The rapid spread of the virus across countries worldwide compels the WHO to declare global pandemic status on March 11, 2020. ${ }^{4}$

Human-to-human transmission of SARS-CoV-2 occurs through close contact and exposure to respiratory droplets, with asymptomatic patients representing a discrete source of infection. ${ }^{5}$

In March 2020, because of the enormous risk of transmission of the infection, the Italian government and other countries adopted restrictive quarantine and lockdown measures to limit the spread of the disease and deaths. On
DOI https://doi.org/

10.1055/s-0041-1734470.

ISSN 1305-7456. (c) 2021. The Author(s).

This is an open access article published by Thieme under the terms of the Creative Commons Attribution License, permitting unrestricted use, distribution, and reproduction so long as the original work is properly cited. (https://creativecommons.org/licenses/by/4.0/)

Thieme Medical and Scientific Publishers Pvt. Ltd., A-12, 2nd Floor, Sector 2, Noida-201301 UP, India 
May 4, 2020, at the end of the quarantine period, phase 2 of the health emergency begins with the gradual reopening of production and commercial activities and the obligation to respect the social distance and the use of masks. ${ }^{6}$ As of June 3 , 2020, inter-regional movement was unblocked, and during the summer months, virus transmission was under control, although there were a few new cases. ${ }^{7}$ In the months between autumn and winter, the increase in COVID casesrecognized as a "second wave"-imposed new restrictive measures by the Italian Government on November 3, 2020. Through 21 parameters inherent to monitoring capacity, degree of diagnostic, investigation and contact tracing capacity, and characteristics of transmission dynamics and resilience of health services, Italian regions were assigned to a color by using the traffic light method. Each Italian region according to high, medium, or low risk level assumed the color red, orange, or yellow, respectively. ${ }^{8}$

In addition to the disastrous effect on the economic balance, the restrictive measures have had a negative impact on people's psychological status. Some recent studies have observed negative effects on mental health due to factors such as loneliness, stress, anxiety, fear of contracting the virus, depression, and sleep disorders. ${ }^{9-11}$ Some studies have analyzed the impact of the pandemic period on lifestyle and eating habits. ${ }^{12,13}$ The increase in sedentariness, the reduction of sports activities, and the condition of continuous psychological stress induced a change in daily diet, recording a higher intake of sweet and carbohydraterich foods. ${ }^{14}$ These foods seem to have a positive effect on the production of serotonin and therefore can provide relief for stress and anxiety. ${ }^{15}$ However, some studies have also observed an improvement in dietary patterns. In fact, increased consumption of fruits and vegetables and a reduction in alcoholic beverages emerged during the pandemic. $^{16,17}$

The pandemic period also affected the perceived risk of infection within dental practices. In fact, Martina et al, through a questionnaire sent to a sample of 1,500 Italian people, observed that $45 \%$ of patients considered the dental practice a place at high risk of contagion and $43 \%$ considered going to the dentist a risk. ${ }^{18}$ Similarly, several studies have highlighted dentists' fear of being infected within their office or infecting people in contact with them. ${ }^{19-22}$

Likewise, a study performed in Spain found that dental practices and hospitals were considered places at increased risk of infection, although $91.6 \%$ of patients were not concerned about contracting the virus in the dental practice. $^{23}$

The aim of the study was to evaluate if COVID-19 affect the psychophysical balance of people, investigating the oral hygiene habits and the type of diet during the pandemic, how the aesthetic was affected by the use of face mask, and the perception of safety of returning to dentist.

\section{Materials and Methods}

This study was conducted by a survey questionnaire sent to the entire population in Italy via Internet in a period between
December 2020 and January 2021. The home page provided information on the scope and purpose of the study.

The survey was created with SurveyMonkey and were transmitted by WhatsApp, Facebook, or e-mail. There were no incentives for participation.

The questionnaire consisted of 21 items that evaluated demographic information; social information; frequency of visit to the dentist before pandemic and possible diagnosis of any disease such as caries, periodontal disease and oral lesions; and changes in home oral hygiene habits. In addition, the questionnaire investigated the influence that the pandemic period had on eating habits, measuring the increase or decrease in consumption of carbohydrates, proteins, fats, sweets, fruits, vegetables, and alcoholic beverages.

Finally, two questions analyzed whether the use of the mask influenced the perception of their smile and facial aesthetics.

The results were transcribed by using an ordinary scale. Participants also had the opportunity to add free text at the end of the questionnaire. We calculated the average time of 5 minutes to complete it.

\section{Statistical Analysis}

The categorical variables were expressed as frequency. Differences in rates were calculated using the Chi-square test. The significance level was set below 0.05 . The statistical program used was the Statistical Package for Social Sciences (SPSS) for Windows, version 12.0.

\section{Results}

A total of 1,008 (413 males and 595 females) individuals completed the survey. Information on the age of the individuals showed that most of the participants were included in the age ranges of 18 to 29 years old $(388 ; 38.5 \%)$ and 30 to 49 years old $(319 ; 31.6 \%)$. About 890 ( $88.3 \%)$ individuals lived at home with family, while the remainder lived alone (94; $9.3 \%)$ or at home with friends $(24 ; 2.4 \%)$. The - Table 1 showed general data of the participants.

A total of 780 (77.4\%) individuals said that they were not afraid when going to the dentist (- Table 2). Of these, $56.2 \%$ $(438 / 780)$ were women $(p=0.001)$. Responses on the frequency of dental visits in the pre-pandemic period showed that most participants visited their dentist once every 6 months $(424 ; 42.1 \%$ ) or once a year (397; 39.4\%). Furthermore, during visits before the pandemic, 313(31.1\%) patients showed the presence of caries, 168 (16.7\%) had been diagnosed with periodontal disease (gingivitis or periodontitis), and 141 (14\%) had altered oral conditions (mouth ulcers, white lesions of the tongue or cheeks, burning of the mouth, and pink lesion). In addition, 198 (19.4\%) people had fixed or removable prostheses in their mouths.

Overall 451 (44.7\%) participants intensified their oral hygiene and preventive rules (mouthwash, flossing, bottle brushing, and feeding) during the pandemic period, especially women; in fact, $63.4 \%$ (286/451) of them were women $(p=0.011)$. 
Table 1 Characteristics of the responders

\begin{tabular}{|c|c|c|c|c|c|}
\hline & \multicolumn{5}{|c|}{ Frequency (percentage) } \\
\hline Age & $\begin{array}{c}18-29 \\
388(38.5 \%)\end{array}$ & \multicolumn{2}{|l|}{\begin{tabular}{|l|}
$30-49$ \\
$319(31.6 \%)$
\end{tabular}} & \multicolumn{2}{|l|}{$\begin{array}{l}50-69 \\
277(27.5 \%)\end{array}$} \\
\hline Gender & \multicolumn{3}{|l|}{$\begin{array}{l}\text { Males } \\
413(41.0 \%)\end{array}$} & \multicolumn{2}{|l|}{$\begin{array}{l}\text { Females } \\
595(59.0 \%)\end{array}$} \\
\hline Residence & \multicolumn{2}{|l|}{$\begin{array}{l}\text { Within the family } \\
890(88.3 \%)\end{array}$} & \multicolumn{2}{|l|}{$\begin{array}{l}\text { Alone } \\
94(9.3 \%)\end{array}$} & $\begin{array}{l}\text { At home with friends } \\
24(2.4 \%)\end{array}$ \\
\hline
\end{tabular}

Table 2 Frequencies and percentages of responses to questions about perceived risk in returning to the dentist, oral condition, and confidence in returning to the dentist

\begin{tabular}{|c|c|c|c|c|c|}
\hline \multirow{3}{*}{$\begin{array}{l}\text { Fear of the dentist } \\
\text { Frequency of dental visits in the } \\
\text { pre-pandemic period }\end{array}$} & \multicolumn{5}{|c|}{ Frequency (percentage) } \\
\hline & \multicolumn{3}{|c|}{ Yes 228 (22.6\%) } & \multicolumn{2}{|l|}{ No $780(77.4 \%)$} \\
\hline & $\begin{array}{l}\text { Never } \\
81(8.0 \%)\end{array}$ & $\begin{array}{l}\text { Once a week } \\
20(2.0 \%)\end{array}$ & $\begin{array}{l}\text { Once a month } \\
86 \\
(8.5 \%)\end{array}$ & $\begin{array}{l}\text { Once every } 6 \text { mo } \\
424(42.1 \%)\end{array}$ & $\begin{array}{l}\text { Once a year } \\
397(39.4 \%)\end{array}$ \\
\hline Diagnosis of caries before the pandemic & \multicolumn{3}{|c|}{ Yes 313 (31.1\%) } & \multicolumn{2}{|l|}{ No 695 (68.9\%) } \\
\hline $\begin{array}{l}\text { Diagnosis of periodontal disease before } \\
\text { the pandemic }\end{array}$ & \multicolumn{3}{|c|}{ Yes 168 (16.7\%) } & \multicolumn{2}{|l|}{ No $840(83.3 \%)$} \\
\hline $\begin{array}{l}\text { Diagnosis of altered oral conditions before } \\
\text { the pandemic }\end{array}$ & \multicolumn{3}{|c|}{ Yes 141 (14.0\%) } & \multicolumn{2}{|l|}{ No 867 (86.0\%) } \\
\hline $\begin{array}{l}\text { Presence of fixed or removable prosthesis } \\
\text { in the mouth }\end{array}$ & \multicolumn{3}{|c|}{ Yes $196(19.4 \%)$} & \multicolumn{2}{|l|}{ No 812 (80.6\%) } \\
\hline $\begin{array}{l}\text { Intensification of oral hygiene and } \\
\text { preventive rules }\end{array}$ & \multicolumn{3}{|c|}{ Yes $451(44.7 \%)$} & \multicolumn{2}{|l|}{ No 557 (55.3\%) } \\
\hline Confidence in returning to the dentist & \multicolumn{3}{|c|}{ Yes 724 (71.8\%) } & \multicolumn{2}{|l|}{ No $284(28.2 \%)$} \\
\hline $\begin{array}{l}\text { Think of carrying out only the most urgent } \\
\text { therapies }\end{array}$ & \multicolumn{3}{|c|}{ Yes 718 (71.2\%) } & \multicolumn{2}{|l|}{ No $290(28.8 \%)$} \\
\hline
\end{tabular}

Since the end of the quarantine, concern about returning to the dentist involved 284 (28.2\%) participants. Notably, among them, 66.9\% (190/284) were women $(p=0.001)$; however, $71.2 \%(718 / 1,008)$ of participants expressed a willingness to perform only the most urgent therapies. Of these, women accounted for $62.3 \%(447 / 718 ; p=0.001)$.

The survey analyzed whether the pandemic period had changed eating habits, and 380 (37.7\%) individuals increased their carbohydrate consumption and 282 (28\%) consumed more fat and 229 (22.7\%) increased protein. Interestingly, fruit intake increased for $405(40.2 \%)$, alcohol or drink consumption decreased for 286 (28.4\%), and remaining unchanged for 564 (56\%) participants. Regarding the consumption of sweets and snacks, there was an increase for 394 (39.1\%) participants, mostly women; in fact, 66.8\% (263/394) of them were women $(p=0.000)$.

The survey explored the opinions about the influence of the mask on aesthetics. For 760 (75.4\%) participants, the mask did not generate aesthetic discomfort, while 246 (24.4\%) believed that wearing a mask diminished the beauty of their smile; specifically, 76.8\% (189/246) of them were females $(p=0.001)$. In addition, 875 (87\%) participants responded that the smile hidden by the mask did not make them more confident about attraction. The data are reported in - Table 3.

\section{Discussion}

The aim of the study was to evaluate if COVID-19 affect the psychophysical balance of people, investigating the oral hygiene habits and the type of diet during the pandemic, how the aesthetic was affected by the use of facemask, and the perception of safety of returning to dentist.

The sample was an acceptable representation of the different age ranges and different work occupations.

In total, $28.2 \%(284 / 1,008)$ of participants expressed concern about returning to the dentist. These values are lower than the results of a previous study conducted at the end of the quarantine period, in which $45.6 \%$ of participants felt it was risky to return to the dentist. ${ }^{18}$

The results showed that of the participants who expressed concern about returning to the dentist, 66.9\% (190/284) were women $(p=0.001)$. This is in agreement with Martina ${ }^{18}$ and Cotrin, ${ }^{24}$ who reported that women had more anxiety and apprehension than men when returning to the dentist.

About $71.2 \%(718 / 1008)$ of participants responded that they would only visit a dentist for emergencies. Notably, $62.3 \%(447 / 718)$ of them were females $(p=0.001)$. The association with women is consistent with a recent study by Peloso et al, who had observed that men were more inclined to go to the dentist than women who would go only for emergencies. ${ }^{25}$ 
Table 3 Frequencies and percentages of responses to questions about changes in eating habits and aesthetics

\begin{tabular}{|c|c|c|c|c|}
\hline & \multicolumn{4}{|c|}{ Frequency (percentage) } \\
\hline Carbohydrate intake during the pandemic & $\begin{array}{l}\text { Decreased } \\
108(10.7 \%)\end{array}$ & \multicolumn{2}{|l|}{$\begin{array}{l}\text { Increased } \\
380(37.7 \%)\end{array}$} & $\begin{array}{l}\text { Unchanged } \\
520 \text { (51.6\%) }\end{array}$ \\
\hline Protein intake during the pandemic & $\begin{array}{l}\text { Decreased } \\
75(7.4 \%)\end{array}$ & \multicolumn{2}{|l|}{$\begin{array}{l}\text { Increased } \\
229(22.7 \%)\end{array}$} & $\begin{array}{l}\text { Unchanged } \\
704(69.8 \%)\end{array}$ \\
\hline Fat intake during the pandemic & $\begin{array}{l}\text { Decreased } \\
184(18.3 \%)\end{array}$ & \multicolumn{2}{|l|}{$\begin{array}{l}\text { Increased } \\
282(28.0 \%)\end{array}$} & $\begin{array}{l}\text { Unchanged } \\
542 \text { (53.8\%) }\end{array}$ \\
\hline Intake of fruits and vegetables during the pandemic & $\begin{array}{l}\text { Decreased } \\
79(7.8 \%)\end{array}$ & \multicolumn{2}{|l|}{$\begin{array}{l}\text { Increased } \\
405(40.2 \%)\end{array}$} & $\begin{array}{l}\text { Unchanged } \\
524 \text { (52.0\%) }\end{array}$ \\
\hline Alcoholic beverage intake during the pandemic & $\begin{array}{l}\text { Decreased } \\
286(28.4 \%)\end{array}$ & \multicolumn{2}{|l|}{$\begin{array}{l}\text { Increased } \\
158(15.7 \%)\end{array}$} & $\begin{array}{l}\text { Unchanged } \\
564(56.0 \%)\end{array}$ \\
\hline Intake of sweets and snacks during the pandemic & $\begin{array}{l}\text { Decreased } \\
190(18.8 \%)\end{array}$ & \multicolumn{2}{|l|}{$\begin{array}{l}\text { Increased } \\
394 \text { (39.1\%) }\end{array}$} & $\begin{array}{l}\text { Unchanged } \\
424(42.1 \%)\end{array}$ \\
\hline Decreased smile beauty from mask use & \multicolumn{2}{|l|}{$\begin{array}{l}\text { Yes } \\
246(24.4 \%)\end{array}$} & \multicolumn{2}{|l|}{$\begin{array}{l}\text { No } \\
760 \text { (75.4\%) }\end{array}$} \\
\hline Smile hidden by mask makes you feel more confident & \multicolumn{2}{|l|}{$\begin{array}{l}\text { Yes } \\
131(13.0 \%)\end{array}$} & \multicolumn{2}{|l|}{$\begin{array}{l}\text { No } \\
875 \text { (86.8\%) }\end{array}$} \\
\hline
\end{tabular}

More than half of the participants (55.3\%; 557) did not intensify oral hygiene and preventive rules (mouthwash, flossing, bottle brushing, and feeding) during the pandemic period showing less interest in oral health. Similarly, PinzanVercelino et al noted that individuals had a lower frequency of tooth brushing and this was closely associated with an increased prevalence of halitosis. ${ }^{26}$

Since the beginning of the pandemic period, there has been a change in eating habits. This has been due to various factors in particular stress and anxiety, greater sedentariness given by smart working, regulations that have reduced people's movements, and changes in the availability of food during the day. ${ }^{27,28}$ Therefore, $37.7 \%(380 / 1,008)$ of participants said that they increased their carbohydrate intake. This increase could result from the prevalence of homemade recipes that primarily included foods such as pizza and bread. ${ }^{14}$ Moreover, 28\% (282) of participants reported increased fat consumption, and increased intake of sweets and snacks was reported in 394 (39.1\%) individuals, particularly in women who accounted for $66.8 \%$ (263/394) of them $(p=0.000)$. Di Renzo et al, by means of a survey addressed to approximately 3,500 Italians, observed a clear change in eating habits and an increase in the consumption of "junk food" and sweets. ${ }^{14}$ The "junk food" consists of foods rich in energy but poor in essential and healthy nutrients. ${ }^{29}$ Further studies observed that the uncontrolled and excessive consumption of this category of food predisposes to the development of chronic pathologies, such as cardiovascular diseases and obesity. ${ }^{30,31}$ Moreover, it should be considered that a diet rich in sweets and snacks can increase the risk of dental caries. ${ }^{32}$ Therefore, it would be important to give people advice to reduce both the quantity and frequency of sugar intake. Surprisingly, $40.2 \%$ (405) of the participants consumed more fruits and vegetables. These results are in agreement with other recent studies that have emphasized increased intake of fresh produce during the quarantine period. ${ }^{33,34}$ Likely, the increased consumption of fruits and vegetables was a function of home cooking and WHO awareness of the importance of eating nutritious foods. ${ }^{35}$ Fruits and vegetables are foods rich in vitamins and minerals, the lack of which increases the risk of obesity and immune system abnormalities by affecting the response against pathogens. ${ }^{14}$

The consumption of alcoholic beverages showed a decrease in 286 (28.4\%) participants being in agreement with some studies reporting an important decrease in alcohol intake in the examined population. ${ }^{34,36}$ One reason that could explain the decrease in alcohol consumption may be the reduction of social occasions and events, especially in the younger category. ${ }^{35}$

The mask, an essential device to reduce the risk of infection of the virus, covers the mouth and perioral area making it more difficult to capture emotional facial expressions such as fear, surprise, sadness, and happiness. This condition can decrease or worsen social communication. ${ }^{26}$ Furthermore, 246 (24.4\%) participants believed that wearing a mask diminished the beauty of their smile; specifically, $76.8 \%$ $(189 / 246)$ of them were females $(p=0.001)$. The result and the association with women are confirmed and can also be explained by a study concluded that women really missed looking at people's smile because of its importance in social relationships. ${ }^{37}$

The lower half of the face is an essential aspect of attractiveness, and the use of the mask may influence the assessment of beauty parameters. ${ }^{38}$ However, 875 (87\%) survey participants responded that the smile hidden by the mask did not make them more confident about attraction but was irrelevant. This may stem from a discrete awareness of one's own beauty and attractiveness. In this regard, Patel et al showed that individuals, who without the mask were defined as medium and high attractiveness, after wearing the mask did not differ and did not further increase their attractiveness. ${ }^{38}$

This study presents some limitations: it is a survey-based study and thus information is self-reported. However, it also 
presents some strengths, such as the high number of participants, the good representation of the population, and its depiction of the situation of Italian dental patients.

\section{Conclusions}

This survey-based study investigated the risk perception of Italian people toward attending dental practices and concerning oral hygiene and dietary habits during the COVID-19 pandemic.

Most of the participants felt comfortable returning to the dentist, but only for therapies that are more urgent. Nevertheless, most people declared that they did not intensify their home oral hygiene measures.

There were changes in the eating habits of the population, in particular an increase in the consumption of carbohydrates, fats, and snacks, but the intake of fruit and vegetables also increased.

Finally, most of the participants answered that the use of the mask did not compromise their aesthetics.

\section{Funding \\ None. \\ Conflict of Interest \\ None declared.}

\section{References}

1 Zhu N, Zhang D, Wang W, et al. China Novel Coronavirus Investigating and Research Team. A novel coronavirus from patients with pneumonia in China, 2019. N Engl J Med 2020;382(08):727-733

2 Sohrabi C, Alsafi Z, O'Neill N, et al. World Health Organization declares global emergency: a review of the 2019 novel coronavirus (COVID-19. [published correction appears in Int J Surg. 2020 May;77:217]Int J Surg 2020;76:71-76

3 Coronaviridae Study Group of the International Committee on Taxonomy of Viruses. The species Severe acute respiratory syndrome-related coronavirus: classifying 2019-nCoV and naming it SARS-CoV-2. Nat Microbiol 2020;5(04):536-544

4 Cascella M, Rajnik M, Aleem A, Dulebohn SC, Di Napoli RFeatures, evaluation, and treatment of coronavirus (COVID-19). In: StatPearls. Treasure Island, FL: StatPearls Publishing; April 20,2021

5 Issakhov A, Zhandaulet Y, Omarova P, Alimbek A, Borsikbayeva A, Mustafayeva A. A numerical assessment of social distancing of preventing airborne transmission of COVID-19 during different breathing and coughing processes. Sci Rep 2021;11(01): 9412

6 Indicazioni Operative Per L'Attività Odontoiatrica Durante La Fase 2 Della Pandemia COVID-19. 2020. Accessed 30 May 2020 at: http://www.salute.gov.it/imgs/C_17_pubblicazioni_2917_allegat.pdf

7 Prezioso C, Pietropaolo V. COVID-19: update of the Italian situation. J Neurovirol 2020;26(06):834-837

8 Paroni L, D’Apice C, Ussai S, et al. The traffic light approach: indicators and algorithms to identify COVID-19 epidemic risk across Italian regions. Front Public Health 2021;9:650243

9 Ganesan B, Al-Jumaily A, Fong KN, Prasad P, Meena SK, Tong RK. Impact of coronavirus disease 2019 (COVID-19) outbreak quarantine, isolation, and lockdown policies on mental health and suicide. Front Psychiatry 2021;12:565190
10 Gunnell D, Appleby L, Arensman E, et al. COVID-19 Suicide Prevention Research Collaboration. Suicide risk and prevention during the COVID-19 pandemic. Lancet Psychiatry 2020;7(06): 468-471

11 Farook FF, Mohamed Nuzaim MN, Taha Ababneh K, Alshammari A, Alkadi L. COVID-19 pandemic: oral health challenges and recommendations. Eur J Dent 2020;14(S 01)S165-S170

12 World Health Organisation. Food and nutrition during selfquarantine: what to choose and how to eat healthily. Available at: https://www.euro.who.int/en/health-topics/disease-prevention/nutrition/news/news/2020/3/food-andnutrition-during-self-quarantine-what-to-choose-and-how-to-eat-healthily. Accessed January 18, 2021

13 Nicola M, Alsafi Z, Sohrabi C, et al. The socio-economic implications of the coronavirus pandemic (COVID-19): a review. Int J Surg 2020;78:185-193

14 Di Renzo L, Gualtieri P, Pivari F, et al. Eating habits and lifestyle changes during COVID-19 lockdown: an Italian survey. J Transl Med 2020;18(01):229

15 Ma Y, Ratnasabapathy R, Gardiner J. Carbohydrate craving: not everything is sweet. Curr Opin Clin Nutr Metab Care 2017;20(04): 261-265

16 Didinger C, Thompson H. Motivating pulse-centric eating patterns to benefit human and environmental well-being. Nutrients 2020;12(11):3500

17 Ammar A, Brach M, Trabelsi K, et al. Effects of COVID-19 home confinement on eating behaviour and physical activity: results of the ECLB-COVID19 International Online Survey. Nutrients 2020; 12(06): $\mathrm{x}$

18 Martina S, Amato A, Faccioni P, Iandolo A, Amato M, Rongo R. The perception of COVID-19 among Italian dental patients: an orthodontic point of view. Prog Orthod 2021;22(01):11

19 Amato A, Ciacci C, Martina S, Caggiano M, Amato M. COVID-19: the dentists' perceived impact on the dental practice. Eur J Dent 2021

20 Umeizudike KA, Ayanbadejo PO, Omidiran DO, et al. Impact of the COVID-19 pandemic on the psychosocial wellbeing of dental therapists in Nigeria. Niger J Med 2021;30:160-166

21 Martina S, Amato A, Rongo R, Caggiano M, Amato M. The perception of COVID-19 among Italian dentists: an orthodontic point of view. Int J Environ Res Public Health 2020;17(12): 4384

22 González-Olmo MJ, Delgado-Ramos B, Ortega-Martínez AR, Romero-Maroto M, Carrillo-Díaz M. Fear of COVID-19 in Madrid. Will patients avoid dental care? Int Dent J 2021S0020-6539(21) 00032-0. Doi: 10.1016/j.identj.2021.01.013

23 González-Olmo MJ, Ortega-Martínez AR, Delgado-Ramos B, Romero-Maroto M, Carrillo-Diaz M. Perceived vulnerability to coronavirus infection: impact on dental practice. Braz Oral Res 2020;34:e044

24 Cotrin P, Peloso RM, Oliveira RC, et al. Impact of coronavirus pandemic in appointments and anxiety/concerns of patients regarding orthodontic treatment. Orthod Craniofac Res 2020;23 (04):455-461

25 Peloso RM, Pini NIP, Sundfeld Neto D, et al. How does the quarantine resulting from COVID-19 impact dental appointments and patient anxiety levels? Braz Oral Res 2020;34:e84

26 Pinzan-Vercelino CR, Freitas KM, Girão VM, da Silva DO, Peloso RM, Pinzan A. Does the use of face masks during the COVID-19 pandemic impact on oral hygiene habits, oral conditions, reasons to seek dental care and esthetic concerns? J Clin Exp Dent 2021;13 (04):e369-e375

27 Robertson M, Duffy F, Newman E, Prieto Bravo C, Ates HH, Sharpe H. Exploring changes in body image, eating and exercise during the COVID-19 lockdown: a UK survey. Appetite 2021; 159:105062 
28 Naja F, Hamadeh R. Nutrition amid the COVID-19 pandemic: a multi-level framework for action. Eur J Clin Nutr 2020;74(08): 1117-1121

29 Fardet A. Characterization of the degree of food processing in relation with its health potential and effects. Adv Food Nutr Res 2018;85:79-129

30 Hall KD, Ayuketah A, Brychta R, et al. Ultra-processed diets cause excess calorie intake and weight gain: an inpatient randomized controlled trial of ad libitum food intake. [published correction appears in Cell Metab. 2019;30(1):226] [published correction appears in Cell Metab. 2020;32(4):690]Cell Metab 2019;30(01): 67-77.e3

31 Azemati B, Kelishadi R, Ahadi Z, et al. Association between junk food consumption and cardiometabolic risk factors in a national sample of Iranian children and adolescents population: the CASPIAN-V study. Eat Weight Disord 2020;25(02):329-335

32 van Loveren $C$. Sugar restriction for caries prevention: amount and frequency. which is more important? Caries Res 2019;53(02):168-175
33 Pietrobelli A, Pecoraro L, Ferruzzi A, et al. Effects of COVID-19 lockdown on lifestyle behaviors in children with obesity living in Verona, Italy: a longitudinal study. Obesity (Silver Spring 2020;28 (08):1382-1385

34 Rodríguez-Pérez C, Molina-Montes E, Verardo V, et al. Changes in dietary behaviours during the COVID-19 outbreak confinement in the Spanish COVIDiet Study. Nutrients 2020;12(06):1730. Doi: 10.3390/nu12061730

35 Bennett G, Young E, Butler I, Coe S. The impact of lockdown during the COVID-19 outbreak on dietary habits in various population groups: a scoping review. Front Nutr 2021;8:626432

36 Scarmozzino F, Visioli F. Covid-19 and the subsequent lockdown modified dietary habits of almost half the population in an Italian sample. Foods 2020;9(05):675

37 Dömötör Z, Nordin S, Witthöft M, Köteles F. Modern health worries: a systematic review. J Psychosom Res 2019;124:109781

38 Patel V, Mazzaferro DM, Sarwer DB, Bartlett SP. Beauty and the mask. Plast Reconstr Surg Glob Open 2020;8(08):e3048 